WSRC-RP--92-418

DE93 009888

\title{
VERIFICATION OF THE GASPAR DOSE ASSESSMENT MODULE USED IN MAXIGASP AND POPGASP
}

D.M. Hamby Plo

December 31, 1992

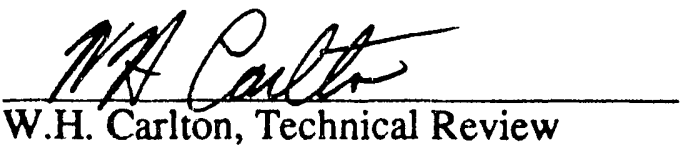

Westinghouse Savannah River Company

Savannah River Technology Center

Aiken, SC 29808 


\section{CONTENTS}

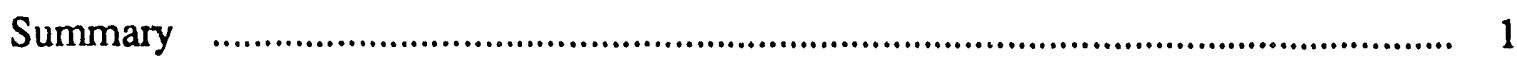

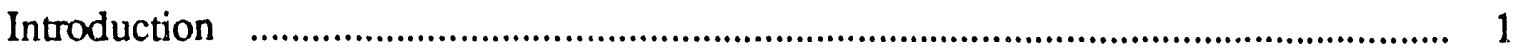

Organization

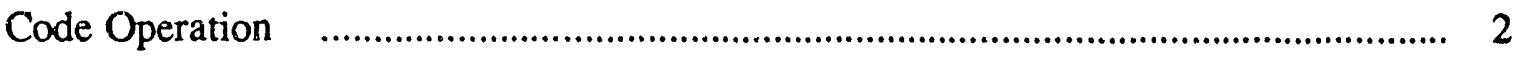

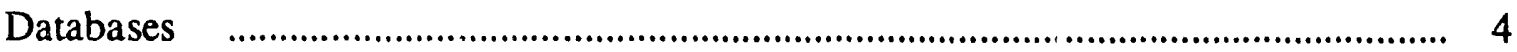

Input from XOQDOQ ……...............................................................................

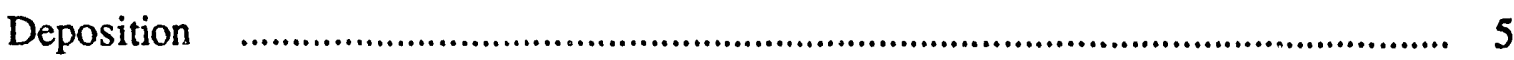

Tritium and Carbon-14

Iodines

Other Nuclides

Nuclide Concentrations in the Atmosphere

Tritium and Carbon-14

Noble Gases

Iodines

Other Nuclides

Nuclide Concentrations in Vegetation

Tritium

Carbon-14

Other Nuclides

Nuclide Concentrations in Meat and Milk _................................................................ 9

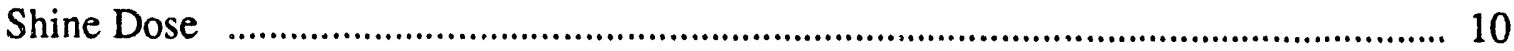

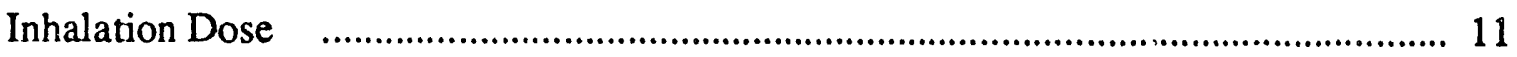

Food Ingestion Dose

Code Verification ……..................................................................................... 13

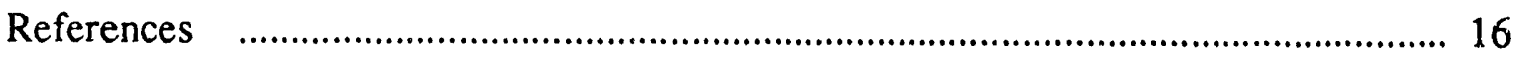




\section{LIST OF FIGURES}

1 GASPAR program schematic diagram ............................................................. 3

\section{LIST OF TABLES}

1 Descriptions of GASPAR subroutines …………............................................ 2

2 Valid input ranges for MAXIGASP and POPGASP .............................................. 4

3 Parameter values for vegetation concetrations ........................................................... 9

4 Parameter assignments in GASPAR for cow and goat milk ingestion dose calculations 10

5 Consumption and population parameters for estimation of vegetation, meat, and milk population dose 13

6 Comparison of GASPAR to hand calculations of maximum individual dose .......... 14

7 Comparison of GASPAR to hand calculations of population dose .......................... 15 


\title{
VERIFICATION OF THE GASPAR DOSE ASSESSMENT MODULE USED IN MAXIGASP AND POPGASP
}

\author{
by D.M. Hamby \\ Westinghouse Savannah River Company \\ Savannah River Site \\ Aiken, SC 29808
}

\section{SUMMARY}

The GASPAR module utilized in MAXIGASP and POPGASP has been verified by hand calculations. The program operates as documented by the NRC [Eckerman et. al. 1980]. Equations used in the code to calculate downwind deposition rates, concentrations in air, on ground surfaces, and in vegetables, meat, and milk are provided in this report.

\section{INTRODUCTION}

The GASPAR code [Eckerman et. al. 1980] was written in 1977 by Oak Ridge National Laboratory for the Nuclear Regulatory Commission (NRC). The models in GASPAR calculate atmospheric concentrations, deposition rates, concentrations in foodstuffs, and radiation dose to individuals and populations resulting from chronic releases of radionuclides to the atmosphere [NRC 1977a]. Brief descriptions of GASPAR's subroutines and a schematic showing the transfer of data are given in Table 1 and Figure 1. The atmospheric transport models that feed GASPAR are contained in XOQDOQ [NRC 1977b; Sagendorf et. al. 1982]. XOQDOQ has been verified to calculate relative concentration $(\mathrm{X} / \mathrm{Q})$ and relative deposition $(\mathrm{D} / \mathrm{Q})$ at specific downwind locations for both maximum individual and population dose estimates [Bauer 1991].

GASPAR was originally designed [Eckerman et. al. 1980] to calculate "ALARA" and "NEPA" population dose estimates. The major difference in these estimates is that doses to the 50-mile population are considered ALARA doses and NEPA doses are calculated for the entire U.S. population. NEPA doses are calculated and printed by GASPAR but are not utilized by the SRS (the no-print option is not available). The NEPA dose calculations are not verified in this or any other SRS document.

\section{ORGANIZATION}

The GASPAR code is made up of twenty-six modules (subroutines, entry points, data blocks, etc.). These modules can be grouped into six classifications of code control: 1) supervision, 2) housekeeping, 3) input data, 4) input subroutines, 5) dose computations, and 6) output. The program diagram in Figure 1 shows the interactions between modules relative to data transfer. GASPAR is arranged so that it operates in either MAXIGASP or POPGASP to calculate radiation doses to humans resulting from atmospheric releases of radionuclides. 
Table 1. Descriptions of GASPAR subroutines

\begin{tabular}{ll}
\hline Subroutine & \multicolumn{1}{c}{ Function } \\
\hline MAIN & Controls input, reads special locations, echos input. \\
DOSIT & Controls and executes computations and controls output. \\
PART & Computes doses of particulates, including iodine. \\
CARBON & Computes Carbon-14 doses. \\
NOBLE & Computes doses from noble gases. \\
TRITON & Computes tritium doses. \\
OUTSPL & Combines with BRKSPL to print individual doses. \\
OUTMAN & Combines with BRKMAN to print integrated population doses. \\
REDDF & Reads and prints dose factor library when requested. \\
SOURCE & Reads and prints source term. Catalogs source term items. \\
REDSIT & Reads and prints site-specific population and agricultural data. \\
REDMET & Reads met. data (printed by PRINTM, called by MAIN). \\
PRINTM & Prints site and met. data. \\
PRINTB & Prints changes to BLOCK DATA made through BLKDAT. \\
PRINTC & Prints cost-benefit table (2 copies). \\
ZERO1 & Zeroes arrays. \\
ZERO2 & Zeroes arrays. \\
ZERO3 & Zeroes arrays. \\
BLKDAT & Reads various consumption and agricultural constants. \\
BLOCK DATA & Data read routine. \\
SRMAXI & Special output for MAXIGASP when JC(1)>0 and JC(6)>0. \\
\hline
\end{tabular}

\section{CODE OPERATION}

Procedures for executing dose calculation programs are given in EDGs Procedure Manual L15.16, "Environmental Dosimetry Procedures". The JCL (Job Control Language) needed to execute MAXIGASP and POPGASP, their input templates, and all accessed databases are maintained on the unclassified IBM Mainframe.

Valid ranges on input queries are given in Table 2. Many of the input parameters appear in MAXIGASP and POPGASP templates, however, the templates are not identical and some parameters are necessary for only one of the two codes, e.g., the choice of cow or goat milk consumption is only available for calculations of the maximum individual dose.

Input for the facility grade parameter is shown to be valid for all values between 0 and 1000 feet. The highest site elevation is approximately 400 feet above sea level, however, a value of 1000 is entered if the flat terrain option is requested. 
Figure 1. GASPAR program schematic diagram.

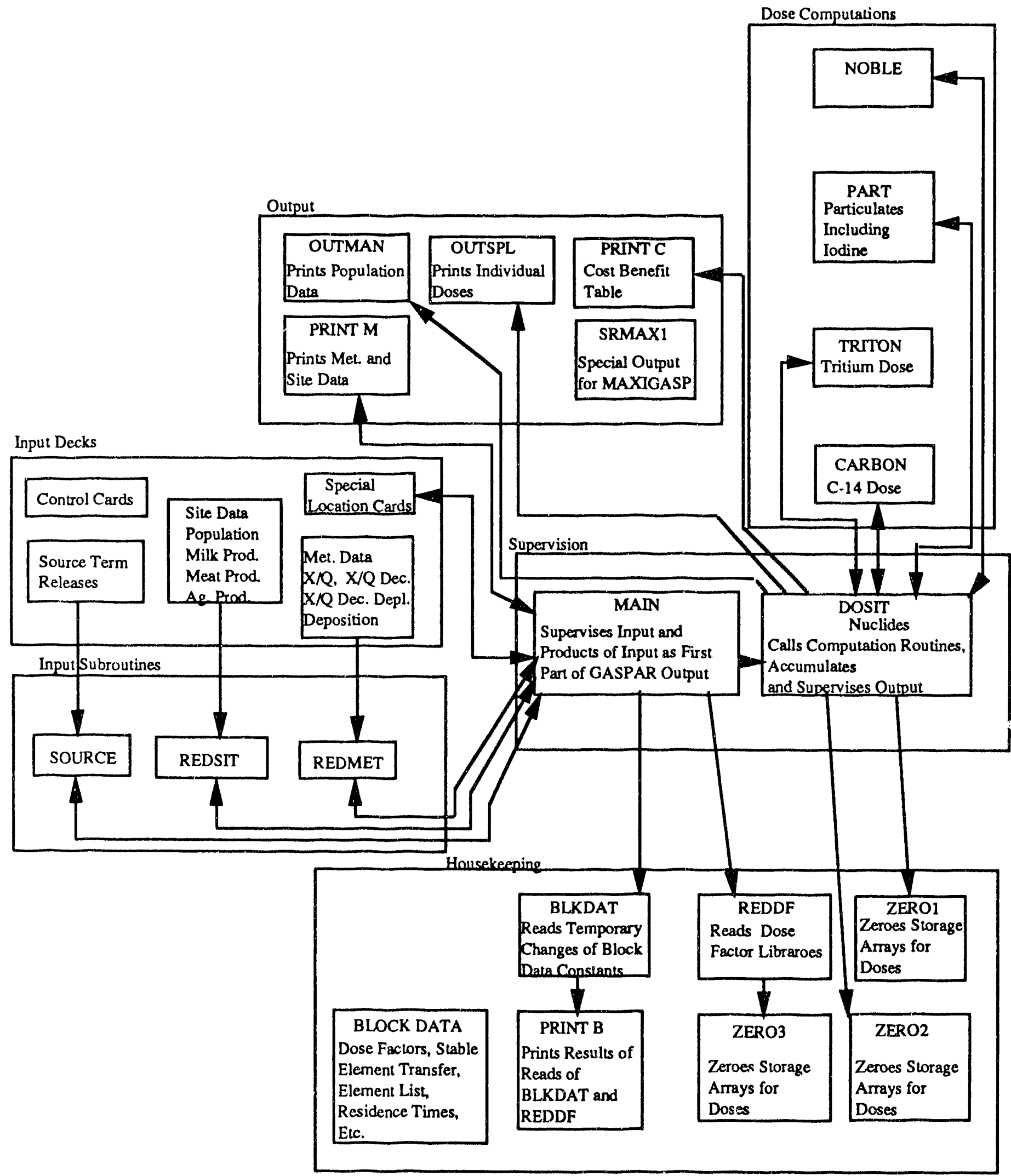


Table 2. Valid input ranges for MAXIGASP and POPGASP.

Parameter

Value

Number of Released Nuclides

Number of Release Points

Operating Period (yr)

Individual Consumption

Milk Ingestion

Facility Grade Elevation (ft)

SRS Easting Coordinate

SRS Northing Coordinate

SRS Tower Met Data

Vent Avg Air Velocity (m/s)

Vent Inside Diameter (m)

Vent/Release Height (m)

Height of Vent's Building (m)

Min. Vertical Cross-Section $\left(\mathrm{m}^{2}\right)$

Selected Wind Height (m)

Heat Emission Rate (cal/s)

Fraction of Elemental Iodines

Release Amount (Ci)

$$
\begin{gathered}
1-100 \\
1-5 \\
1-201 \\
\text { MAX; AVG } \\
\text { COW; GOAT } \\
0-1000 \\
\text { any onsite value } \\
\text { any onsite value } \\
\mathrm{A}, \mathrm{C}, \mathrm{D}, \mathrm{F}, \mathrm{H}, \mathrm{K}, \text { or } \mathrm{P} \\
0-1000 \\
0-50 \\
0-100 \\
0-100 \\
0-10000 \\
0-100 \\
0-500 \\
0-1 \\
\text { zero }-10^{6}
\end{gathered}
$$

\section{DATABASES}

Dose factors utilized in the calculation of atmospheric dose are maintained in two separate databases on the unclassified IBM mainframe and are accessed by the GASPAR module of MAXIGASP and POPGASP. One database exists for noble gases and the other contains all other nuclides. They include decay constants and external gammashine, inhalation, and ingestion dose factors for each radionuclide. The noble gas library has only decay constants and external cloud-shine dose factors. Other parameter values, such as stable element transfer coefficients, cattle feeding rates, buildup times, usage rates, etc. are coded directly into the FORTRAN as block-data subroutines.

The dose factor libraries, DFGAS30 and NDFMANEW, are resident in the TENVT.DATA.TMECA dataset and have been verified for accuracy [Hamby $1991 \mathrm{~b}$; Hamby 1991c]. Hardcopies of the libraries are maintained in EDG records as QA documentation.

\section{INPUT FROM XOQDOQ}

MAXIGASP and POPGASP access the same atmospheric transport and dosimetry models in the NRC codes XOQDOQ and GASPAR. XOQDOQ models the transport of radionuclides through the atmosphere while GASPAR estimates radiation dose to individuals or populations. Differences in MAXIGASP and POPGASP are seen upon examination of the input and output modules as well as the data transfer subroutines, however, the two computer codes access the same versions of XOQDOQ and GASPAR. 
The transport models of XOQDOQ are described in the NRC Regulatory Guide 1.111 [1977b] and verified by Bauer [1991]. When calculating downwind air concentrations for radionuclides, the Regulatory Guide 1.111 states:

"For conservative estimates of radioactive decay, an overall half-life of 2.26 days is acceptable for short-lived noble gases and of 8 days for all iodines released to the atmosphere. Alternatively, the actual half-life of each radionuclide may be used. The decay time used should be the calculated time of travel between the source and receptor based on the airflow model used."

For radionuclide transport at the SRS, actual radioactive decay is calculated for each nuclide released to the atmosphere. GASPAR accepts only four outputs from the XOQDOQ computer code: 1) relative air concentration, X/Q;2) relative air concentration decayed by 2.26 days; 3 ) relative air concentration decayed and depleted for 8 days; and 4) relative deposition, $D / Q$. The nondecayed $X / Q$ and the 2.26 day decayed $X / Q$ are used to calculate the travel time from the source to the receptor (see section on deposition).

\section{DEPOSITION}

Deposition of iodines and particulates can occur by several mechanisms. The primary removal mechanism of atmospheric material is gravitational settling or contact with the ground, vegetation, or other ground cover such as buildings (dry deposition). Wet deposition, whereby gases and particulates are removed from an atmospheric plume by precipitive scavenging (rain, sleet, snow). For long-term averages, such as those calculated in MAXIGASP and POPGASP, dose calculations considering only dry deposition are not usually changed significantly by the consideration of wet deposition [NRC 1977b]. Wet deposition should be considered at sites that have a well-defined rainy season corresponding to the grazing season [NRC 1977b].

Rainfall at the SRS averages 48.2 inches annually (from 1952 to 1987). Average monthly rainfall rates range between 2.5 and 5 inches per month. The SRS does not have a rainy season, however, the months of November and December typically have less rain than other months [Hunter 1990]. Since there is not a well-defined rainy season, wet deposition would be insignificant at the SRS for long-term averages. It is, therefore, not considered in MAXIGASP and POPGASP.

Tritium and Carbon-14. Dry deposition of these nuclides is not considered. Specific activity models for tritium and C-14 utilize atmospheric concentrations to estimate vegetation concentrations.

Iodines. Deposition rates, $\mathrm{d}_{\mathrm{i}}$, for iodine isotopes are estimated using,

$$
\mathrm{d}_{\mathrm{i}}\left[\frac{\mu \mathrm{Ci}}{\mathrm{m}^{2} \mathrm{yr}}\right]=\frac{\mathrm{D}}{\mathrm{Q}}\left[\frac{1}{\mathrm{~m}^{2}}\right] \cdot \mathrm{Q}_{\mathrm{i}}\left[\frac{\mathrm{Ci}}{\mathrm{yr}}\right] \cdot \mathrm{F}_{1} \cdot 10^{6}\left[\frac{\mu \mathrm{Ci}}{\mathrm{Ci}}\right] \cdot \mathrm{e}^{\left(31.62-\lambda_{\mathrm{i}}\right) \xi_{\mathrm{t}}}
$$

where $D / Q$ is the relative deposition value calculated in XOQDOQ, $Q_{i}$ is the radionuclide release rate, $F_{I}$ is the fraction of iodine that is assumed to be elemental, $\lambda_{i}$ is the nuclidespecific decay constant and $t_{\mathrm{T}}$ is the plume travel time from the source to the receptor. Iodine-131 establishes a deposition equilibrium on ground surfaces with a half-life of 
approximately 8 days [Till 1983]. Deposition equilibrium with an eight-day half-life is assumed for all nuclides. The factor of $31.62 \mathrm{yr}^{-1}$ in the exponent accounts for this equilibrium. The iodine deposition rate equation includes a factor to account for the fraction of the release that is in elemental form. The fraction in the gaseous form does not deposit on ground surfaces.

The parameter $t_{T}$ is the average amount of time required for the effluent to reach the receptor (site boundary for maximum individual calculations or specific annular distance for population calculations). The XOQDOQ program calculates a decayed and a nondecayed $\chi / Q$. The decayed $\chi / Q$ is obtained by assuming the effluent is radioactive with a half-life of 2.26 days [NRC 1977b]. The value of $\mathrm{t}_{\mathrm{T}}$ is found by solving the radioactive decay equation used in XOQDOQ to calculate a 2.26 day decayed relative air concentration,

$$
\frac{\chi_{D}}{Q}=\frac{\chi}{Q} \mathrm{e}^{-\left(112 y r^{-1}\right) t_{T}}
$$

where the value $112 \mathrm{yr}^{-1}$ is the decay constant for a 2.26 day half-life. The effluent travel time (in years) is then,

$$
\mathfrak{t}_{\mathrm{T}}=\frac{-\ln \left(\frac{\chi \mathrm{D} / \mathrm{Q}}{\chi / \mathrm{Q}}\right)}{\left(\frac{\ln 2 \cdot 365 \mathrm{~d}}{2.26 \mathrm{~d} \cdot 1 \mathrm{yr}}\right)}
$$

where $\chi_{\mathrm{D}} / \mathrm{Q}$ and $\chi / \mathrm{Q}$ are the decayed and non-decayed relative air concentrations at the receptor and are obtained from XOQDOQ output. The plume travel time is used in subsequent equations to account for radioactive decay, ground deposition, and plume depletion.

Other Nuclides. Deposition rates for all remaining nuclides are determined using,

$$
\mathrm{d}_{\mathrm{i}}\left[\frac{\mu \mathrm{Ci}}{\mathrm{m}^{2} \mathrm{yr}}\right]=\frac{\mathrm{D}}{\mathrm{Q}}\left[\frac{1}{\mathrm{~m}^{2}}\right] \cdot \mathrm{Q}_{\mathrm{i}}\left[\frac{\mathrm{Ci}}{\mathrm{yr}}\right] \cdot 10^{6}\left[\frac{\mu \mathrm{Ci}}{\mathrm{Ci}}\right] \cdot \mathrm{e}^{\left(31.62-\lambda_{i}\right) \mathrm{s}}
$$

where all parameters have been previously defined. The deposition equilibrium coefficient for iodine $\left(31.62 \mathrm{yr}^{-1}\right)$ is applied to all other nuclides as well. Deposition is modeled for all radionuclides other than tritium, carbon-14, and noble gases.

\section{NUCLIDE CONCENTRATIONS IN THE ATMOSPHERE}

Tritium and Carbon-14. Downwind atmospheric concentrations, $\chi_{i}$, of tritium and C-14 are estimated using,

$$
\chi_{i}\left[\frac{\mu \mathrm{Ci}}{\mathrm{m}^{3}}\right]=\frac{\chi}{\mathrm{Q}}\left[\frac{\mathrm{sec}}{\mathrm{m}^{3}}\right] \cdot \mathrm{Q}_{\mathrm{i}}\left[\frac{\mathrm{Ci}}{\mathrm{yr}}\right] \cdot 10^{6}\left[\frac{\mu \mathrm{Ci}}{\mathrm{Ci}}\right] \cdot 3.17 \times 10^{-8}\left[\frac{\mathrm{yr}}{\mathrm{sec}}\right]
$$

Since both tritium and carbon- 14 have relatively long half-lives, radiological decay is not taken into account when estimating downwind concentration for these nuclides. 
Noble Gases. Air concentrations of noble gases are estimated by,

$$
\chi_{i}\left[\frac{\mu \mathrm{Ci}}{\mathrm{m}^{3}}\right]=\frac{\chi}{\mathrm{Q}}\left[\frac{\mathrm{sec}}{\mathrm{m}^{3}}\right] \cdot \mathrm{Q}_{\mathrm{i}}\left[\frac{\mathrm{Ci}}{\mathrm{yr}}\right] \cdot 10^{6}\left[\frac{\mu \mathrm{Ci}}{\mathrm{Ci}}\right] \cdot 3.17 \times 10^{-8}\left[\frac{\mathrm{yr}}{\mathrm{sec}}\right] \cdot \mathrm{e}^{\lambda_{i t r}}
$$

where the exponential accounts for radioactive decay during transit to the maximum individual receptor. The value of $\mathrm{t}_{\mathrm{T}}$ is determined in the same manner as for the calculation of deposition rate.

Iodines. Iodine concentrations in the atmosphere are determined using,

$$
\chi_{i}\left[\frac{\mu C i}{m^{3}}\right]=\left\{\left(\frac{\chi_{D}}{Q} \cdot\left(1-F_{I}\right)\right)+\left(\frac{\chi D D}{Q} \cdot F_{I} \cdot e^{31.62 t_{T}}\right)\right\}\left[\frac{\sec }{m^{3}}\right] \cdot Q_{i}\left[\frac{\mu C i}{s e c}\right] \cdot e^{\lambda_{1} t_{T}}
$$

where the $\chi_{\mathrm{D}}$ represents a decayed concentration and $\chi_{\mathrm{DD}}$ represents a decayed and depleted concentration. The factor in brackets calculates a weighted relative air concentration accouting for the deposition of the elemental fraction. The exponential term in brackets accounts for deposition equilibrium and is applied only to the depleted $\chi / Q\left(\chi_{\mathrm{DD}}\right)$ An exponential term is also included in this equation to account for radioactive decay during plume transit.

Other Nuclides. Air concentrations of the remaining nuclides (those not considered above), are calculated using,

$$
\chi_{i}\left[\frac{\mu \mathrm{Ci}}{\mathrm{m}^{3}}\right]=\frac{\chi_{\mathrm{DD}}}{\mathrm{Q}}\left[\frac{\mathrm{sec}}{\mathrm{m}^{3}}\right] \cdot \mathrm{Q}_{\mathrm{i}}\left[\frac{\mathrm{Ci}}{\mathrm{yr}}\right] \cdot 10^{6}\left[\frac{\mu \mathrm{Ci}}{\mathrm{Ci}}\right] \cdot 3.17 \times 10^{-8}\left[\frac{\mathrm{yr}}{\mathrm{sec}}\right] \cdot \mathrm{e}^{\left(31.62-\lambda_{i} x_{T}\right.}
$$

where all terms have been defined previously. Again, the positive rate coefficient in the exponential term ( $\left.31.62 \mathrm{yr}^{-1}\right)$ accounts for deposition equilibrium between the air and ground surface.

\section{NUCLIDE CONCENTRATIONS IN VEGETATION}

Tritium. A specific activity model describes the uptake of tritium in vegetation. Tritium concentrations in vegetation are determined directly from the concentrations of tritium in atmospheric moisture. Equilibrium is assumed to be achieved in a short time relative to an annual release. The concentration of tritium in vegetation, $C_{\mathrm{T}}^{\mathrm{v}}$, is determined by,

$$
C_{\mathrm{T}}^{\mathrm{v}}\left[\frac{\mu \mathrm{Ci}}{\mathrm{kg}}\right]=\frac{\chi_{\mathrm{T}}\left[\frac{\mu \mathrm{Ci}}{\mathrm{m}^{3}}\right] \cdot 0.75 \cdot 0.5}{\mathrm{H}\left[\frac{\mathrm{kg}}{\mathrm{m}^{3}}\right]}
$$

where $\chi_{\mathrm{T}}$ is the atmospheric concentration, 0.75 is the fraction of plant mass that is water, 0.5 is the assumed concentration ratio of plant tritium to atmospheric tritium, and $\mathrm{H}$ is the annual average absolute humidity $\left(11 \mathrm{~g} / \mathrm{m}^{3}\right.$ for the SRS). Studies [Bauer and Hamby, 1991; Hamby 1992] show that dose estimates for the vegetation consumption pathway 
are somewhat sensitive to the parameters in this model. A site-specific value is being developed for the plant-tritium-to-atmospheric-tritium ratio.

Carbon-14. The C-14 model for vegetation concentrations is similar to the tritium model. The equation,

$$
C_{C}^{v}\left[\frac{\mu C i}{\mathrm{~kg}}\right]=\frac{\chi_{C}\left[\frac{\mu \mathrm{Ci}}{\mathrm{m}^{3}}\right] \cdot \mathrm{F}_{\mathrm{t}} \cdot 0.11}{0.00016\left[\frac{\mathrm{kg}}{\mathrm{m}^{3}}\right]}
$$

is used to estimate $C-14$ vegetation concentrations, $C_{C}^{v}$. The parameter $F_{t}$ is defined as the ratio of the total annual release time to the total annual time during which photosynthesis occurs (taken to be 4380 hours). If atmospheric releases occur more than half the year, the value of $F_{t}$ is unity. The fraction of total plant mass that is natural carbon is represented by 0.11 and 0.00016 is the concentration of natural carbon in the atmosphere.

Other Nuclides. The concentration of other nuclides in vegetation is determined using,

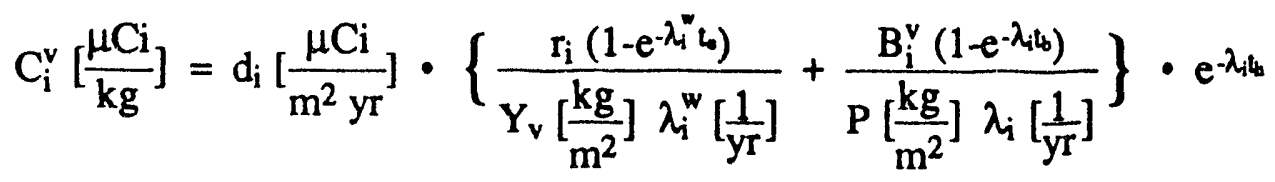

where $d_{i}$ is the deposition rate determined earlier, $r_{i}$ is the fraction of the nuclide deposited that remains on the surface of the plant, $\lambda_{i}^{\prime \prime}$ represents both weathering and radioactive losses, $t_{t}$ is the crop exposure time, $Y_{v}$ is the crop productivity, $B_{i}^{v}$ is the element-specific soil/plant uptake ratio, $\lambda_{i}$ is the radioactive decay constant, $t_{b}$ is the time over which the buildup of radionuclides occurs, $\mathrm{P}$ is the surface soil density, and $t_{h}$ is the hold-up time after harvest (allowing for decay before consumption).

The two expressions in the brackets account for contamination via foliar deposition and root uptake, respectively. All particulate nuclides are assumed to be fully retained on vegetation $(r=1)$ while only $20 \%$ of the iodines are retained $(r=0.2)$. The loss constant , $\lambda_{i}^{*}$, accounts for losses through physical weathering (14 day half-life) and radioactive decay. Values of $Y_{v}, t_{e}$, and $t_{h}$ vary depending on the type of crop and whether the vegetation is for human consumption or is to be used as fodder [Hamby 1991a].

Concentrations in four types of vegetation are calculated in GASPAR. These four types along with their associated parameter values are given in Table 3. 
Table 3. Parameter values for vegetation concentrations.

\begin{tabular}{lcccc}
\hline Parameter & $\begin{array}{c}\text { Other } \\
\text { Vegetables }\end{array}$ & $\begin{array}{c}\text { Leafy } \\
\text { Vegetables }\end{array}$ & $\begin{array}{c}\text { Pasture } \\
\text { Grass }\end{array}$ & $\begin{array}{c}\text { Stored } \\
\text { Feed }\end{array}$ \\
\hline$r$ (iodines) & 0.2 & same & same & same \\
$r$ (particulates) & 1.0 & same & same & same \\
$\lambda_{\mathrm{w}}\left(\mathrm{yr}^{-1}\right)$ & $18.07+\lambda_{\mathrm{i}}$ & same & same & same \\
$\mathrm{t}_{\mathrm{e}}(\mathrm{yr})$ & 0.192 & 0.192 & 0.0822 & 0.192 \\
$\mathrm{Y}_{\mathrm{v}}\left(\mathrm{kg} \mathrm{m}^{-2}\right)$ & 0.7 & 0.7 & 1.8 & 0.7 \\
$\mathrm{~B}_{\mathrm{i}}$ & element specific & same & same & same \\
$\lambda_{\mathrm{i}}\left(\mathrm{yr}^{-1}\right)$ & nuclide specific & same & same & same \\
$\mathrm{t}_{\mathrm{b}}(\mathrm{yr})$ & scenario specific & same & same & same \\
$\mathrm{P}\left(\mathrm{kg} \mathrm{m}^{-2}\right)$ & 240 & same & same & same \\
$\mathrm{t}_{\mathrm{h}}(\mathrm{yr})$ & $0.164(0.0384)^{*}$ & 0.00274 & 0 & 0.247 \\
$\mathrm{~d}_{\mathrm{i}}\left(\mu \mathrm{Ci} \mathrm{m}{ }^{-3} \mathrm{yr}^{-1}\right)$ & nuclide specific & same & same & same \\
\hline
\end{tabular}

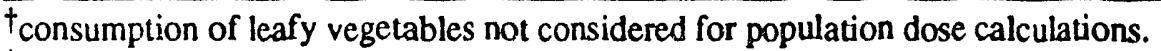

*value in parentheses is for population dose calculations.

\section{NUCLIDE CONCENTRATIONS IN MEAT AND MILK}

All Nuclides. Concentrations of radionuclides in meat and milk are determined from feed concentrations, fodder intake rates, and element-specific feed-to-meat/feed-to-milk transfer factors. The equations for meat and milk concentration estimates are essentially identical with the exception of the feed transfer coefficient. Concentrations are estimated using,

$$
\begin{aligned}
& C_{i}^{\text {meat }}\left[\frac{\mu C i}{k g}\right]=C_{i}^{\text {fodder }}\left[\frac{\mu C i}{k g}\right] \cdot F_{i}^{f}\left[\frac{d}{k g}\right] \cdot Q_{F}\left[\frac{k g}{d}\right] \cdot e^{\lambda_{i}} \\
& C_{i}^{\text {milk }}\left[\frac{\mu C i}{L}\right]=C_{i}^{\text {fodder }}\left[\frac{\mu C i}{k g}\right] \cdot F_{i}^{m}\left[\frac{d}{L}\right] \cdot Q_{F}\left[\frac{k g}{d}\right] \cdot e^{\lambda_{i} \psi}
\end{aligned}
$$

where $C_{i}^{\text {fodder }}$ is the nuclide concentration in cattle feed (determined below), $F_{i}^{f}$ and $F_{i}^{m}$ are the feed transfer coefficients, $Q_{F}$ is the cattle feed rate. The exponential term accounts for radiological decay from the time of slaughter/milking to the time of consumption where $\lambda_{i}$ is the nuclide-specific decay constant, $t_{g}$ is the transport time for rieat, and $t_{f}$ is the transport time for milk. Values for these parameters are given in Table 4. 
Table 4. Parameter assignments in GASPAR for meat and milk ingestion dose calculations ${ }^{\dagger}$.

Parameter Meat Milk (cow) Milk (goat)

Feed consuription rate $(\mathrm{kg} / \mathrm{d})$

Milking/Slaughter to consumption (d)

- Fraction of year on pasture

Fraction intake from pasture*

Milk (goat)

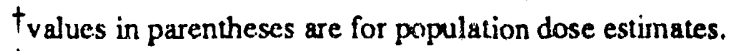

while on pasture.

The nuclide concentration in fodder is estimated based on the fraction of time cattle spend on pasture and the fraction of that time that is spent consuming fresh pasture grass. The equation,

$$
C_{i}^{\text {fodder }}\left[\frac{\mu C i}{k g}\right]=f_{p} f_{s} C_{i}^{p}\left[\frac{\mu C i}{k g}\right]+\left\{f_{p}\left(1-f_{s}\right)+\left(1-f_{p}\right)\right\} C_{i}^{s}\left[\frac{\mu C i}{k g}\right]
$$

is used to calculate a fodder concentration by weighting the concentrations of pasture grass, $C_{i}^{p}$, and stored feed, $C_{i}^{s}$. The parameter $f_{p}$ is the fraction of time cattle spend on pasture and $f_{s}$ is the fraction of time that cattle eat fresh grass while on pasture.

Concentrations of nuclides in goat's milk are determined in the same manner as cow's milk and beef except using different values (see Table 4) for feed consumption rate and the fraction of time spent on pasture and eating pasture grass.

\section{SHINE DOSE}

Plume-Shine. Dose to offsite individuals and the population from gamma shine is estimated in GASPAR only for the noble gases. The plume-shine dose from these nuclides has been determined to be significantly higher than doses resulting from other nuclides [NRC 1977a]. The gamma dose from a particular noble gas in an atmospheric plume is calculated from,

$$
D_{i}^{p}[\mathrm{mrem}]=\chi_{i}\left[\frac{\mu \mathrm{Ci}}{\mathrm{m}^{3}}\right] \cdot S F \cdot \mathrm{DF}_{\mathrm{i}}^{\mathrm{p}}\left[\frac{\mathrm{mrem} \mathrm{m}^{3}}{\mathrm{yr} \mu \mathrm{Ci}}\right] \cdot 1[\mathrm{yr}]
$$

where $S F$ is a shielding factor accouting for the fraction of time spent indoors and $D F_{i}^{p}$ is the nuclide specific plume-shine dose factor. The value of SF is taken to be 0.7 for individuals, meaning that the individual is assumed to be exposed $70 \%$ of the time.

Population dose is estimated using average plume concentrations in each of 160 sector/annulus segments; 16 sectors and 10 annuli with distance ranges of $0-1,1-2,2-3$, $3-4,4-5,5-10,10-20,20-30,30-40$, and 40-50 miles. Population dose from plume shine is calculated using the following equation: 


$$
D_{i}^{p}[\text { per-rem }]=D F_{i}^{p}\left[\frac{m^{2 r e m ~ m} m^{3}}{y r \mu C i}\right] \cdot 1[y r] \cdot S F \cdot \sum_{k=1}^{160}\left\{\chi_{i k}\left[\frac{\mu C i}{m^{3}}\right] \cdot N_{k} \text { [persons] }\right\}
$$

where $\chi_{i k}$ is the plume concentration of nuclide $i$ in area-segment $k, N_{k}$ is the number of people (all ages) residing within each population segment, and SF is equal to 0.5 . The age distribution of the population is not considered for this pathway because external dose is independent of age.

Ground-Shine. Ground-shine doses are calculated for all particulate, gamma-emitting nuclides. The dose accounts for buildup over the plant lifetime and is given by,

$$
D_{i}^{g}[\mathrm{mrem}]=d_{i}\left[\frac{\mu C i}{m^{2} y r}\right] \cdot S F \cdot D F_{i}^{g}\left[\frac{m r e m m^{2}}{y r \mu C i}\right] \cdot \frac{1-e^{-\lambda_{i t}}}{\lambda_{i}}[y r] \cdot 1[y r]
$$

where $\mathrm{DF}_{\mathrm{i}}^{\mathrm{g}}$ is the nuclide-specific ground-shine dose factor and the exponential term accounts for the ground-surface buildup and subsequent radiological decay. Nuclidespecific doses are summed for the total dose.

The population dose from ground-shine is calculated using,

$D_{i}^{g}[$ per-rem $]=D_{i}^{g}\left[\frac{m_{r e m ~ m}^{2}}{y r \mu C i}\right] \cdot 1[y r] \cdot S F \cdot \frac{1-e^{-\lambda_{i l}}}{\lambda_{i}}[y r] \cdot \sum_{k=1}^{160}\left\{d_{i k}\left[\frac{\mu C i}{m^{3} y r}\right] \cdot N_{k}\right.$ [persons] $\}$

where $d_{\mathrm{ik}}$ is the deposition rate of nuclide $\mathrm{i}$ in area-segment $\mathrm{k}$. Again, external dose is independent of age, therefore, the age distribution of the population is not considered.

\section{INHALATION DOSE}

Inhalation dose is determined for the maximum individual and the population assuming a constant breathing rate and a constant concentration throughout the year of exposure. The nuclide-specific dose is estimated by,

$$
\mathrm{D}_{\mathrm{i}}^{\mathrm{inh}}[\mathrm{mrem}]=\chi_{\mathrm{i}}\left[\frac{\mu \mathrm{Ci}}{\mathrm{m}^{3}}\right] \cdot \mathrm{BR}\left[\frac{\mathrm{m}^{3}}{\mathrm{yr}}\right] \cdot \mathrm{DF}_{\mathrm{i}}^{\mathrm{inh}}\left[\frac{\mathrm{rem}}{\mu \mathrm{Ci}}\right] \cdot 1000\left[\frac{\mathrm{mrem}}{\mathrm{rem}}\right] \cdot 1[\mathrm{yr}]
$$

where $B R$ is the breathing rate and $D F_{i}^{i n h}$ is the nuclide-specific inhalation dose factor. $A$ breathing rate of $8000 \mathrm{~m}^{3} / \mathrm{yr}$ is assumed for maximum individual and population dose estimates in GASPAR.

If age-specific dose factors are available, population dose for age-group $p$, due to the inhalation of radionuclides in the air is given by,

$D_{i p}^{i n h}[$ per-rem $]=D F_{i p}^{\text {inh }}\left[\frac{r e m}{\mu C i}\right] \cdot B R_{p}\left[\frac{m^{3}}{y r}\right] \cdot 1[y r] \cdot f_{p} \cdot \sum_{k=1}^{160}\left\{\chi_{i k}\left[\frac{\mu C i}{m^{3}}\right] \cdot N_{k}\right.$ [persons $\left.]\right\}$

where $B R_{p}$ is the average breathing rate for age-group $p$ and $f_{p}$ is the fraction of the population in the $\mathrm{p}$ age-group. If age-specific dose factors are not available, adult dose 
factors are used with adult breathing rates and the whole population is assumed to be adult. POPGASP is currently configured to calculate population dose under the assumption that the population is $100 \%$ adult.

\section{FOOD INGESTION DOSE}

Dose to the maximum individual is estimated for ingestion of foodstuffs including vegetables, meat, and milk. Radionuclide intakes through the vegetation consumption pathway considers vegetables as being classified as either "leafy" or "other". "Other" includes fruits, grains, produce, and below ground vegetables. The dose via vegetable consumption for a one-year period is calculated using,

$$
D_{i}^{v e g}[m r e m]=\left\{C_{i}^{v} U^{v} f_{v}+C_{i}^{l} U^{l} f_{l}\right\}\left[\frac{\mu C i}{y r}\right] \cdot D F_{i}^{\text {ing }}\left[\frac{\text { rem }}{\mu C i}\right] \cdot 1000\left[\frac{\mathrm{mrem}}{\text { rem }}\right] \cdot 1[y r]
$$

where $C_{i}^{l}$ and $C_{i}^{v}$ are radionuclide concentrations in the leafy and other vegetables, $U^{l}$ and $\mathrm{U}^{\mathrm{v}}$ are consumption rates of the two vegetable classifications, $f_{1}$ is the fraction of leafy vegetables consumed that originated in the home garden, and $f_{v}$ is the fraction of other vegetables that are home grown.

Individual dose from meat and milk consumption is calculated in the same manner, using the equations:

$$
\begin{aligned}
& D_{i}^{\text {meat }}[\text { mrem }]=C_{i}^{\text {meat }}\left[\frac{\mu C i}{\mathrm{~kg}}\right] \cdot U^{f}\left[\frac{\mathrm{kg}}{\mathrm{yr}}\right] \cdot \mathrm{DF}_{\mathrm{i}}^{\mathrm{ing}}\left[\frac{\mathrm{rem}}{\mu \mathrm{Ci}}\right] \cdot 1000\left[\frac{\mathrm{mrem}}{\mathrm{rem}}\right] \cdot 1[\mathrm{yr}] \\
& D_{i}^{\text {milk }}[\mathrm{mrem}]=\mathrm{C}_{\mathrm{i}}^{\text {milk }}\left[\frac{\mu \mathrm{Ci}}{\mathrm{L}}\right] \cdot U^{m}\left[\frac{\mathrm{L}}{\mathrm{yr}}\right] \cdot \mathrm{DF}_{\mathrm{i}}^{\text {ing }}\left[\frac{\mathrm{rem}}{\mu \mathrm{Ci}}\right] \cdot 1000\left[\frac{\mathrm{mrem}}{\mathrm{rem}}\right] \cdot 1[\mathrm{yr}]
\end{aligned}
$$

where the parameters have already been defined. The ingestion dose factor, $\mathrm{DF}_{\mathrm{i}}^{\mathrm{ing}}$, is nuclide-specific and is the same value for water, vegetable, meat, and milk consumption.

ALARA population dose is calculated by GASPAR based on the assumption that the food consumed by the population within 50 miles of the SRS center is produced in the 50-mile region. If production rates exceed consumption needs, food is exported from the region (consumption of which is included in the NEPA dose estimate). Equations for the estimation of age-specific population dose via consumption of vegetables, meat, and milk are given below.

$$
\begin{aligned}
& D_{i p}^{v e g}[\text { per-rem }]=D_{i p}^{\text {ing }}\left[\frac{\mathrm{rem}}{\mu C i}\right] \cdot 1[y r] \cdot f_{p} \cdot U_{p}^{v}\left[\frac{k g}{y r}\right] \cdot N[p e r] \cdot \sum_{k=1}^{160}\left\{C_{i k}^{\text {eg }}\left[\frac{\mu C i}{k g}\right] \cdot \frac{V_{E G}}{V E G T}\right\} \\
& D_{i p}^{\text {meat }}[\text { per-rem }]=D F_{i p}^{\text {ing }}\left[\frac{\mathrm{rem}}{\mu \mathrm{Ci}}\right] \cdot 1[\mathrm{yr}] \cdot \mathrm{f}_{\mathrm{p}} \cdot \mathrm{U}_{\mathrm{p}}^{\mathrm{f}}\left[\frac{\mathrm{kg}}{\mathrm{yr}}\right] \cdot \mathrm{N}[\mathrm{per}] \cdot \sum_{\mathrm{k}=1}^{160}\left\{\mathrm{C}_{\mathrm{ik}}^{\text {meal }}\left[\frac{\mu \mathrm{Ci}}{\mathrm{kg}}\right] \cdot \frac{\mathrm{MET}_{\mathrm{k}}}{\mathrm{METT}}\right\}
\end{aligned}
$$


$D_{i p}^{\text {milk }}[$ per-rem $]=D F_{i p}^{\text {ing }}\left[\frac{\mathrm{rem}}{\mu C i}\right] \cdot 1[y r] \cdot f_{p} \cdot U_{p}^{m}\left[\frac{L}{y r}\right] \cdot N[$ per $] \cdot \sum_{k=1}^{160}\left\{C_{i k}^{\text {milk }}\left[\frac{\mu C i}{L}\right] \cdot \frac{M L K_{k}}{M L K T}\right\}$

Dose factors, $\mathrm{DF}_{\mathrm{ip}}^{\mathrm{ing}}$, and consumption rates, $\mathrm{U}_{\mathrm{p}}$, are age-specific and the parameter $\mathrm{N}$ represents the number of persons served by the total production within an $80-\mathrm{km}$ radius of the site (see Table 5). The consumption of home-grown leafy vegetables is not considered when calculating population dose. Therefore, the rate for vegetable consumption is that for non-leafy or produce. The subscript, p, signifies the age group to which the dose factor applies.

Table 5. Consumption and population parameters for estimation of vegetable, meat, and milk population dose.

\begin{tabular}{lcccc}
\hline Parameter & Units & Vegetable & Meat & Milk \\
\hline Consumption Rate & $\mathrm{kg} / \mathrm{yr}$ & 163 & 43 & 120 \\
Pop. Served & persons & $3.09 \times 10^{5}$ & $3.39 \times 10^{5}$ & $9.25 \times 10^{5}$ \\
Total Production & $\mathrm{kg}$ & $5.041 \times 10^{7}$ & $1.457 \times 10^{7}$ & $1.110 \times 10^{8}$ \\
\hline
\end{tabular}

The parameter $C_{i k}$ is the average concentration of nuclide $i$ in vegetation, meat, or milk within area-segment $k$. The variables $\mathrm{VEG}_{\mathbf{k}}, \mathrm{MET}_{\mathbf{k}}$, and $\mathrm{MLK}_{\mathbf{k}}$ represent the mass of commodity produced in area-segment $k$ and VEGT, METT, and MLKT are the total production mass within $80-\mathrm{km}$. The expressions that follow the summation symbols provide a weighted nuclide concentration for estimating the average nuclide concentration in foods within the dose assessment region.

\section{CODE VERIFICATION}

Concentrations of foodstuffs, etc. do not appear in the MAXIGASP and POPGASP output. Therefore, for the purposes of comparison to hand calculations, only final dose estimates were compared to the computer output. Eight example problems of MAXIGASF have been executed and compared to an EXCEL spreadsheet developed for the purpose of verifying GASPAR. Output from the XOQDOQ portion of MAXIGASP was used as input to the spreadsheets. All dose estimates calculated by MAXIGASP (GASPAR) are identical (within rounding) to spreadsheet calculations (see Table 6). The IBM mainframe printouts and spreadsheet hardcopies are maintained in EDG QA files. 
Table 6. Comparison of GASPAR to hand calculations of maximum individual dose.

Nuclide

GASPAR $^{\dagger}$ Hand-Calculation ${ }^{\dagger} \quad \%$ Diff.

\begin{tabular}{llll}
$\mathrm{H}-3$ & $9.2 \times 10^{-7}$ & $9.1 \times 10^{-7}$ & 1.1 \\
$\mathrm{C}-14$ & $3.6 \times 10^{-4}$ & $3.6 \times 10^{-4}$ & - \\
$\mathrm{Ar}-41$ & $1.4 \times 10^{-6}$ & $1.4 \times 10^{-6}$ & - \\
$\mathrm{Co}-60$ & $1.3 \times 10^{-1}$ & $1.3 \times 10^{-1}$ & - \\
$\mathrm{Se}-75$ & $4.9 \times 10^{-3}$ & $4.9 \times 10^{-3}$ & - \\
$\mathrm{Kr}-85$ & $3.9 \times 10^{-9}$ & $3.9 \times 10^{-9}$ & - \\
$\mathrm{Kr}-85 \mathrm{~m}$ & $2.3 \times 10^{-7}$ & $2.3 \times 10^{-7}$ & - \\
$\mathrm{Kr}-87$ & $7.7 \times 10^{-7}$ & $7.7 \times 10^{-7}$ & - \\
$\mathrm{Kr}-88$ & $3.8 \times 10^{-6}$ & $3.8 \times 10^{-6}$ & - \\
$\mathrm{Sr}-90$ & $6.2 \times 10^{-2}$ & $6.2 \times 10^{-2}$ & - \\
$\mathrm{Zr}-95$ & $3.6 \times 10^{-3}$ & $3.6 \times 10^{-3}$ & - \\
$\mathrm{Nb}-95$ & $1.6 \times 10^{-3}$ & $1.6 \times 10^{-3}$ & - \\
$\mathrm{Ru}-103$ & $2.1 \times 10^{-3}$ & $2.1 \times 10^{-3}$ & - \\
$\mathrm{Ru}-106$ & $3.1 \times 10^{-2}$ & $3.1 \times 10^{-2}$ & - \\
$\mathrm{I}-129$ & $6.7 \times 10^{-1}$ & $6.7 \times 10^{-1}$ & - \\
$\mathrm{I}-131$ & $9.1 \times 10^{-3}$ & $9.1 \times 10^{-3}$ & - \\
$\mathrm{I}-133$ & $1.4 \times 10^{-4}$ & $1.4 \times 10^{-4}$ & - \\
$\mathrm{I}-135$ & $1.4 \times 10^{-5}$ & $1.4 \times 10^{-5}$ & - \\
$\mathrm{Xe}-131 \mathrm{~m}$ & $1.5 \times 10^{-8}$ & $1.5 \times 10^{-8}$ & - \\
$\mathrm{Xe}-133$ & $6.0 \times 10^{-8}$ & $6.0 \times 10^{-8}$ & - \\
$\mathrm{Xe}-135$ & $3.9 \times 10^{-7}$ & $3.9 \times 10^{-7}$ & - \\
$\mathrm{Cs}-134$ & $8.2 \times 10^{-2}$ & $8.2 \times 10^{-2}$ & - \\
$\mathrm{Cs}-137$ & $1.4 \times 10^{-1}$ & $1.4 \times 10^{-1}$ & - \\
$\mathrm{Ce}-141$ & $3.9 \times 10^{-4}$ & $3.9 \times 10^{-4}$ & - \\
$\mathrm{Ce}-144$ & $8.1 \times 10^{-3}$ & $8.1 \times 10^{-3}$ & - \\
$\mathrm{Os}-185$ & $3.8 \times 10^{-3}$ & $3.8 \times 10^{-3}$ & - \\
$\mathrm{U}-234$ & $5.7 \times 10^{-1}$ & $5.7 \times 10^{-1}$ & - \\
$\mathrm{U}-235$ & $5.7 \times 10^{-1}$ & $5.7 \times 10^{-1}$ & - \\
$\mathrm{U}-238$ & $5.2 \times 10^{-1}$ & $5.2 \times 10^{-1}$ & - \\
$\mathrm{Np}-237$ & $3.3 \times 10^{0}$ & $3.3 \times 10^{0}$ & - \\
$\mathrm{Pu}-238$ & $3.1 \times 10^{-1}$ & $3.1 \times 10^{0}$ & - \\
$\mathrm{Pu}-239$ & $3.4 \times 10^{-1}$ & $3.4 \times 10^{-1}$ & - \\
$\mathrm{Am}-241$ & $3.6 \times 10^{0}$ & $3.6 \times 10^{0}$ & - \\
$\mathrm{Cm}-242$ & $9.2 \times 10^{-2}$ & $9.2 \times 10^{-2}$ & - \\
$\mathrm{Cf}-252$ & $1.8 \times 10^{0}$ & $1.8 \times 10^{0}$ & - \\
& $8.0 \times 10^{-1}$ & $8.0 \times 10^{-1}$ & \\
\hline
\end{tabular}

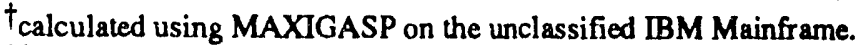

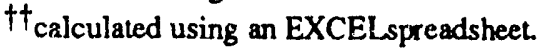


Because of the complexity of calculating population dose in each of 160 area-segments, population dose calculations have been hand-checked using two nuclides, tritium and Argon-41. Methods for calculating population dose for a given pathway are identical for each nuclide, therefore, checks using various nuclides are not necessary. The inhalation and consumption pathways are verified using tritium and the plume-shine pathway is verified by Ar-41. The ground-shine doses were not verified in the population dose calculation since verification was accomplished for individual doses and since the calculation is similar to plume-shine dose. The population dose module of GASPAR was checked by using the EXCEL spreadsheet and summing the cumulative doses in each of the 160 area-segments. Because of the number of mathematical steps involved, slightly larger rounding differences are expected between POPGASP and hand-calculated results. Differences by pathway did not exceed $3 \%$ nor did they exceed $1.5 \%$ for the total dose calculation. The results from this comparison are shown in Table 7.

Table 7. Comparison of GASPAR to hand calculations of population dose.

Pathway GASPAR $^{\dagger}$ Hand-Calculation ${ }^{\dagger \dagger} \%$ Diff.

\begin{tabular}{llcc} 
Plume-Shine $^{*}$ & $3.5 \times 10^{-5}$ & $3.5 \times 10^{-5}$ & 0 \\
Inhalation & $3.6 \times 10^{-5}$ & $3.5 \times 10^{-5}$ & 2.8 \\
Vegetable Consumption & $7.4 \times 10^{-6}$ & $7.6 \times 10^{-6}$ & 2.7 \\
Meat Consumption & $1.2 \times 10^{-6}$ & $1.2 \times 10^{-6}$ & 0 \\
Milk Consumption & $4.3 \times 10^{-6}$ & $4.2 \times 10^{-6}$ & 2.4 \\
TOTAL & $8.4 \times 10-5$ & $8.3 \times 10^{-5}$ & 1.2 \\
\hline
\end{tabular}

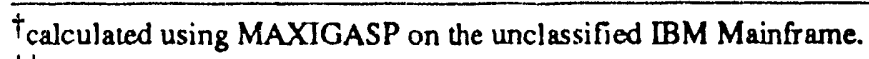

${ }^{+}$calculated using an EXCELspreadsheet similar to that used for maximum individual dose with modifications to calculate average dose in a given area-segment.

plume-shine estimated for 1 curie of $\mathrm{Ar}-41$. 


\section{REFERENCES}

Bauer, L.R., "Modelling Chronic Atmospheric Releases at the SRS: Evaluation and Verification of XOQDOQ", WSRC-RP-91-320, Westinghouse Savannah River Company, Aiken, SC, March 1991.

Bauer, L.R. and Hamby, D.M., "Relative Sensitivities of Existing and Novel Model Parameters in Atmospheric Tritium Dose Estimates", Rad. Prot. Dosimetry, Vol. 37, No. 4, pp. 253-260, 1991.

Eckerman, K.F., Congel, F.J., Roecklein, A.K., and Pasciak, W.J., "User's Guide to GASPAR Code", NUREG/-0597, U.S. Nuclear Regulatory Commission, Washington, DC, June 1980.

Hamby, D.M., "Land and Water-Use Characteristics in the Vicinity of the Savannah River Site", WSRC-RP-91-17, Westinghouse Savannah River Company, Aiken, SC, March 1991.

Hamby, D.M., "Verification of the GASPAR ICRP30 Dose Factor Library", SRL-ETS910583, Savannah River Laboratory, Aiken, SC, December 9, 1991.

Hamby, D.M., "Verification of the GASPAR Noble Gas Dose Factor Library and SRS Site-Specific Datat", SRL-ETS-910585, Savannah River Laboratory, Aiken, SC, December 10, 1991.

Hamby, D.M., "A Probabilistic Estimation of Atmospheric Tritium Dose", WSRC-MS92-321, Westinghouse Savannah River Company, Aiken, SC, accepted for publication in Health Physics, December 1992.

Hunter, C.H., "A Climatological Description of the Savannah River Site", WSRC-RP-89313, Westinghouse Savannah River Company, Aiken, SC, May 22, 1990.

Sagendorf, J.F., Goll, J.T., and Sandusky, W.F., "XOQDOQ: Computer Program for the Meteorological Evaluation of Routine Effluent Releases at Nuclear Power Stations", NUREG/CF-2919, U.S. Nuclear Regulatory Commission, Washington, DC, September 1982.

Till, J.E. and Meyers, H.R. (eds), Radiological Assessment, NUREG/CF-3332, U.S. Nuclear Regulatory Commission, Washington, DC, September 1983.

U.S. Nuclear Regulatory Commission, "Calculation of Annual Doses to Man from Routine Releases of Reactor Effluents for the Purpose of Evaluating Compliance with 10 CFR Part 50, Appendix I", Regulatory Guide 1.109, Rev. 1, Washington, DC, October 1977.

U.S. Nuclear Regulatory Commission, "Methods for Estimating Atmospheric Transport and Dispersion of Gaseous Effluents in Routine Releases from Light-Water-Cooled Reactors", Regulatory Guide 1.111, Rev. 1, Washington, DC, July 1977. 

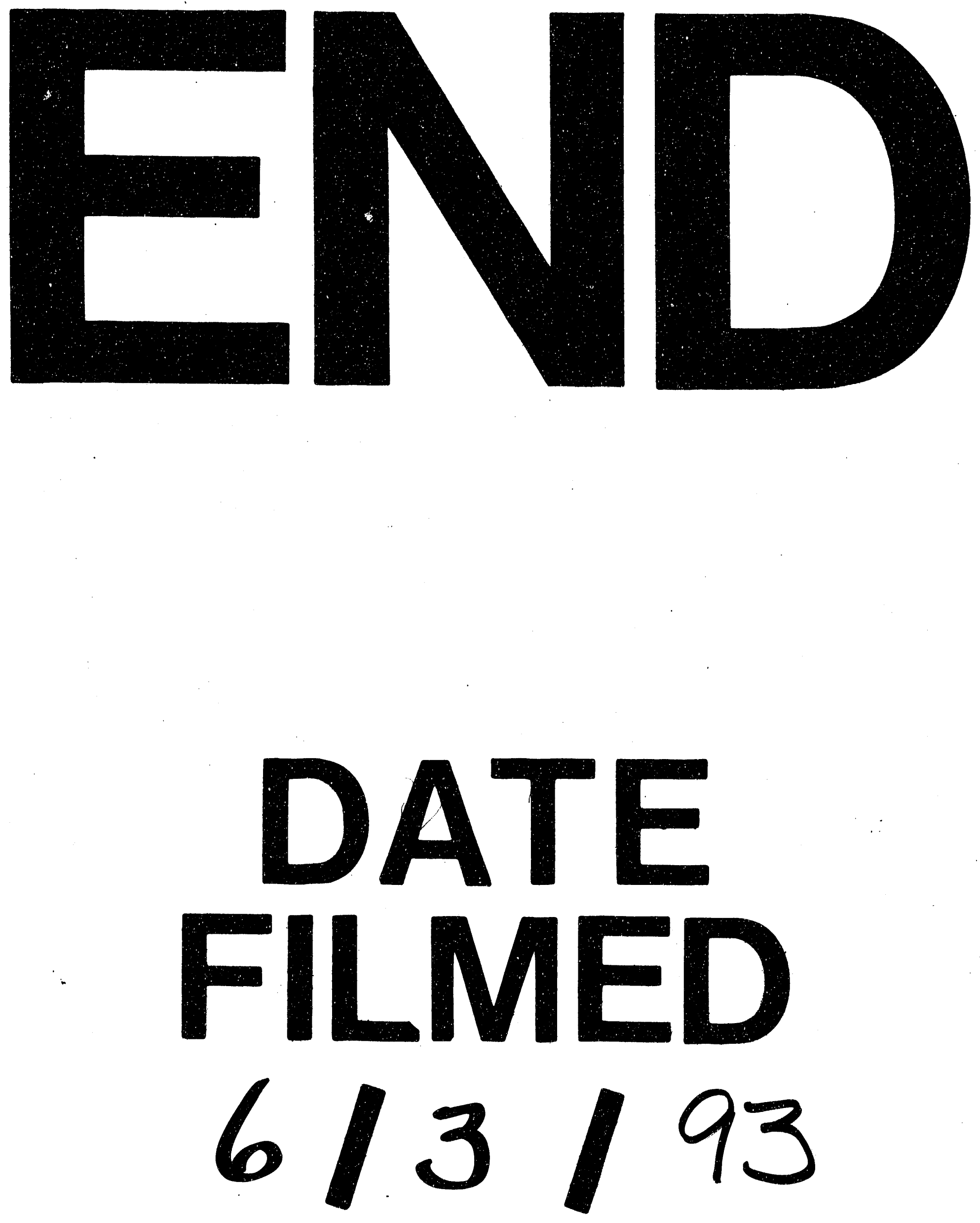
